\title{
PENGELOLAAN MEDIA SEBAGAI SARANA PROMOSI USAHA WARUNG BAKSO MAHKOTA
}

\author{
Diah Ayu Candraningrum ${ }^{1}$, Farid Rusdi ${ }^{2}$, dan Zita Retno Hapsari ${ }^{3}$ \\ ${ }^{1}$ Mahasiswa Program Doktor Ilmu Komunikasi Universitas Indonesia dan Pengajar pada Program Studi Ilmu \\ Komunikasi Universitas Tarumanagara \\ Email: diahc@fikom.untar.ac.id \\ ${ }^{2}$ Mahasiswa Program Doktor Ilmu Komunikasi Universitas Padjajaran dan Program Studi Ilmu Komunikasi \\ Universitas Tarumanagara \\ Email: farid@fikom.untar.ac.id \\ ${ }^{3}$ Program Studi Ilmu Komunikasi Universitas Tarumanagara \\ Email: zitah@fikom.untar.ac.id
}

\begin{abstract}
The digital era brings positive and negative benefits. One of them is experienced by the community of small and medium enterprises (SMEs). Underinformation and inability to keep up with developments are one of the weaknesses of this small-scale business, especially in popularizing business ventures and products sold. This problem is felt by SMEs who have been operating for decades, whose next generation as managers, are challenged to be able to continue the success by combining offline and online promotional media. The importance of supporting small-scale industries is the responsibility of all parties. Not only the government, but also society including academics. Therefore, the PKM team of the Faculty of Communication, Tarumanagara University will help carry out PKM program to assist Bakso Mahkota in their business development, especially in promoting through the media and applying social marketing techniques to help targeting consumer behavior. This activity will be carried out through the implementation of training or workshops to socialize or introduce modern management activities to SMEs. This activity will be attended by 9 small industries which will involve sources including representatives of GoFood or Grabfood, rating websites and restaurant reviews from Zomato or Openrice, representatives of culinary rubric media and foodbloggers. In addition, there will be an explanation from Fikom Untar as the provider of material according to expertise, about the concept of modern management to the fostered partners, so that they are able to understand the material in more detail and be able to achieve the achievement according to the target.
\end{abstract}

Keyword: modern marketing, meatball stalls, MSE

ABSTRAK
Era digital membawa banyak perubahan dalam kehidupan masyarakat, baik manfaat positif dan negatif. Salah satunya dialami oleh masyarakat pelaku usaha kecil menengah (UKM). Ketertinggalan informasi dan ketidakmampuan mengikuti perkembangan, menjadi salah satu kelemahan bisnis skala kecil ini, khususnya dalam mempopulerkan usaha bisnis dan produk yang dijual. Pukulan ini utamanya sangat dirasakan oleh pelaku UKM yang telah beroperasi sejak puluhan tahun lalu, yang generasi penerusnya sebagai pengelola, ditantang untuk bisa meneruskan kesuksesan usaha di masa lalu dengan memadukan media promosi offline dan online. Pentingnya dukungan terhadap industri berskala kecil, adalah tanggung jawab semua pihak. Tidak hanya pemerintah, tapi juga masyarakat termasuk para akademisi. Karena itu, tim PKM Fakultas Ilmu Komunikasi UniversitasTarumanagara akan membantu melaksanakan program kegiatan PKM untuk membantu pelaku UKM Bakso Mahkota dalam pengembangan bisnisnya, terutama dalam melakukan promosi melalui media dan penerapan teknik pemasaran sosial yang diharapkan dapat membantu perilaku target konsumen. Kegiatan ini akan dilakukan melalui pelaksanaan pelatihan atau workshop untuk sosialisasi atau pengenalan kegiatan manajemen modern kepada usaha kecil menengah. Kegiatan ini akan diikuti oleh sekitar 9 pelaku industry kecil yang akan melibatkan narasumber di antaranya dari perwakilan pihak GoFood atau Grabfood, website pemeringkat dan review restoran Zomato atau Openrice, perwakilan media peliput rubric kuliner dan kalangan foodblogger. Selain itu, akan ada penjelasan dari pihak Fikom Untar selaku pemberi materi sesuai kepakaran, tentang konsep manajemen modern kepada pihak mitra binaan, supaya mampu memahami materi lebih detil dan mampu meraih pencapaian sesuai target.

Kata Kunci: pemasaran modern, warung bakso, UKM

\section{PENDAHULUAN}

Di era digital yang mendatangkan banyak perubahan ini, masyarakat dituntut untuk bisa beradaptasi dan juga bersahabat dengan teknologi. Termasuk juga mereka para pelaku bisnis berskala besar dan juga UKM berskala kecil. Para pelaku industri ini, khususnya industri kecil 
UKM, perlumempersiapkan langkah kolaboratif dalam menghadapi transformasi digital. Sebab, hal ini merupakan urusan yang sangat penting bagi bisnis UKM, yang kebanyakan masih mengandalkan model dagang fisik konvensional (Wahyudi, 2017).

Transformasi digital tersebut telah menghasilkan "kedaruratan" bagi setiap brand dan pemilik usaha di Indonesia. Karena rata-rata para pelaku bisnis tersebut tidak memiliki kemampuan beradaptasi dengan teknologi.

Hal-hal bersifat darurat tadi meliputi: ketidaksiapan brand dan pemilik usaha terhadap perubahan dunia dan teknologi yang begitu cepat dan dinamis. Serta era globalisasi pasar bebas, yang membuat waktu menjadi sempit untuk UKM melakukan persiapan. Kondisi ini mengharuskan produk-produk dalam negeri mempunyai daya saing yang tidak kalah dengan barang impor.

Hal ini bukan tanpa alasan, karena banyak sekali pedagang usaha kuliner skala kecil seperti bakso, soto, siomay, sate, dan sebagainya yang masih gagap ketika berhadapan dengan teknologi. Inilah yang menjadi tugas pemerintah dan asosiasi - asosiasi, seperti Asosiasi Laundry, dan komunitas komunitas lain untuk bisa mensosialisasikan serta memberikan pelatihan, seperti e-commerce, internet marketing, dan sebagainya (Rahayu, 2017).

Masalah ini pun seyogyanya bukanlah masalah yang dialami oleh pelaku usaha kecil menengah saja. Kegagapan berhubungan dengan teknologi pun mengancam pelaku bisnis berskala besar, bahkan brand global. Disrupsi atau gangguan bisnis pun dialami oleh perusahaan besar berskala internasional seperti Toys"R"Us yang berbasis di Amerika Serikat. Perusahaan retail penjual produk mainan dan boneka anak - anak di seluruh dunia ini terpaksa mengakhiri bisnisnya karena tidak bisa beradaptasi dengan dunia digital.

Perusahaan raksasa mainan ini harus kalah oleh para pemain baru yang justru bersifat local bahkan individual. Sebagai pemain besar yang telah lama berkecimpung di bidang tersebut, Toys"R"Us seharusnya memiliki kepedulian dengan para pemain baru yang bisa menjadi ancaman. Sebagai output, dia bisa melakukan inovasi untuk memberikan sesuatu yang berbeda kepada konsumennya, sehingga dia tidak akan kehilangan mereka. Namun kenyataannya, sulit bagi perusahaan ini untuk beradaptasi apalagi melakukan berbagai inovasi (Candraningrum, 2018)

Berdasarkan survei yang dilakukan Asosiasi Penyedia Jasa Internet Indonesia tahun 2016, berdasarkan usia, pengguna internet di Indonesia cukup berimbang antara usia 10-24 tahun (18,4\%), 25-34 tahun (24,4\%), 35-44 tahun (29,2\%), 45-54tahun (18\%), dan 55 tahun keatas (10\%). Tapi penetrasi pengguna internet lebih dari 75 persen adalah dari usia 25-34 tahun dan 1024 tahun. Melihat komposisi pengguna internet yang ada di Indonesia, saat ini beberapa media daring berupaya untuk menyasar khalayak mereka dari kalangan generasi muda (Rusdi, 2017).

Kisah sedih juga dialami sebuah warung bakso berskala kecil. Karena tidak cepat menyesuaikan diri dengan digitalisasi, bisnis yang dilakukan pun sempat mengalami goncangan. Warung Bakso Mahkota didirikan oleh orang tua dari M. Taufik. S sejak tahun 1980. Dari dulu mereka setia menjual bakso dan dapat dikatakan sangat laris. Salah satu sebabnya, karena sejak kehadirannya, warung bakso ini tidak memiliki kompetitor. Alhasil, warung bakso ini dapat dikatakan cukup berhasil karena mampu menghidupi keluarga.

Namun sejak beberapa tahun terakhir, keberadaan warung bakso ini mulai dikepung oleh kompetitor. Di wilayah tersebut, saat ini telah hadir dua warung bakso yang juga menawarkan produk yang sama, dengan harga yang bersaing. Karena itu, keberadaan warung dengan empat 
karyawan ini mulai terancam.

Dari segi pendapatan usaha pun, bisnis kuliner ini mengalami penurunan yang berarti. Pada tahun 90an hingga 2000an awal, rata-rata setiap harinya bisa lebih dari 150 mangkok yang berhasil dijual. Tapi dalam waktu beberapa tahun terakhir, penjualannya mengalami penurunan, yakni hanya 100 mangkok per harinya. Karena mereka menjual semangkuk bakso dengan harga relatif lebih tinggi dari rata-rata harga semangkuk bakso lazimnya, yakni sekitar Rp 20 ribu per mangkok. Pengelola warung bakso tidak melakukan kegiatan promosi untuk mengenalkan kepada masyarakat mengenai keberadaan warung tersebut. Pihak pengelola pun tidak melakukan inovasi produk yang dijual sehingga terkesan monoton.

Dari penjelasan di atas, tim pengusul Program Pengabdian Kepada Masyarakat (PKM) dari Fikom Untar merangkum dua permasalahan utama yang dihadapi Kios Bakso Mahkota sebagai pengelola dan penyelenggara UKM bisnis kuliner skala kecil. Masalah tersebut adalah:

1. Menurunnya jumlah pengunjung karena tidak adanya kegiatan promosi yang dilakukan oleh pihak pengelola warung bakso. Ditinjau dari aspek komunikasi pemasaran khususnya kegiatan promosi, yakni tidak adanya strategi berpromosi atau kegiatan promosi untuk meningkatkan jumlah pengunjung kios bakso yang terus menurun setiap harinya.

2. Persaingan yang cukup ketat di lokasi berdirinya warung bakso. Tidak hanya persaingan dalam bentuk fisik atau kasatmata, melainkan juga persaingan dengan penggunaan media digital. Ditinjau dari aspek komunikasi digital, pengelola kios bakso Mahkota belum menggunakan konsep promosi modern yang bertumpu pada media digital.

\section{METODE PELAKSANAAN PKM}

Kegiatan ini terdiri atas sebuah kegiatan pelatihan atau workshop. Dalam kurun waktu dilaksanakan rangkaian kegiatan HUT Untar, akan dilakukan sebuah kegiatan pelatihan, yang bertujuan untuk sosialisasi atau pengenalan kegiatan manajemen modern kepada usaha kecil menengah.

Kegiatan ini akan dilakukan di lokasi mitra dengan diikuti oleh sekitar 10 pelaku industri kecil di sekitar lokasi mitra. Saat kegiatan workshop dilakukan, diharapkan beberapa perwakilan pelaku bisnis sejenis dapat berpartisipasi sebagai peserta sehingga mereka bisa mendapatkan pengetahuan baru yang bisa jadi merupakan solusi bagi masalah bisnis mereka.

Kegiatan ini akan melibatkan narasumber dari perwakilan dari pihak jasa transportasi online delivery food service GoFood atau GrabFood; atau website pemeringkat dan review restoran Zomato, atau menghadirkan perwakilan media peliput kuliner, baik cetak, online maupun elektronik atau dari kalangan foodblogger.

Makna dari penyelenggaraan kegiatan ini adalah, pihak pelaku UKM kuliner mendapatkan pengetahuan tentang konsep manajemen komunikasi pemasaran modern dan juga kegiatan pendampingan kepada pihak mitra binaan.

Kegiatan PKM menggunakan beberapa metode yang saling terkait. Pada tahap awal tim Fikom melakukan riset untuk memetakan permasalahan dan solusi yang tepat. Kemudian, dicarilah sosok mitra yang mampu menggambarkan permasalahan yang dihadapi tadi lewat jaringan pertemanan dan jejaring sosial yang dimiliki. Setelah diperoleh mitra, barulah kemudian dipersiapkan kegiatan yang akan diselenggarakan bersama.

Tim melakukan wawancara dengan setiap peserta, untuk menggantikan pembagian kuesioner, 
terkait tingkat pemahaman mereka tentang permasalahan yang dihadapi dalam menjalankan bisnisnya. Daftar pertanyaan tadi juga sangat bermanfaat dalam mengevaluasi dan memberikan masukan untuk peningkatan materi dan metode pelatihan.

Adapun tahapan pelaksanaan yang digunakan dalam kegiatan ini meliputi beberapa langkah sebagai berikut:

1. Tim PKM Fikom Untar mengajukan permohonan kepada calon mitra pemilik dan pengelola Warung Bakso Mahkota untuk bersama menyelenggarakan kegiatan seminar sebagai bagian dari kegiatan pengabdian kepada masyarakat yang dijalankan.

2. Tim PKM Fikom Untar mendapatkan persetujuan pemilik dan pengelola Warung Bakso Mahkota untuk menjadi mitra. Selanjutnya, mulailah dilakukan diskusi bersama baik lewat offline maupun online, mengenai perencanaan kegiatan dan materi yang disampaikan. Tidak lupa, pembahasan mengenai peserta kegiatan juga menjadi poin utama yang dibahas, karena dalam kegiatan PKM kali ini, akan menghadirkan pedagang kaki lima yang menjadi pesertanya.

3. Tim PKM Fikom Untar membuat proposal terkait kebutuhan tersebut.

4. Proposal tim PKM Fikom Untar disetujui oleh DPPM dan dana kegiatan dicairkan.

5. Tim PKM Fikom Untar akhirnya memilih lokasi di sekitar Kampus 1 Universitas Tarumanagara, dengan alasan kedekatan lokasi dengan kampus dan juga karena adanya permasalahan teknis sehingga kegiatan tidak bisa diselenggarakan di lokasi mitra.

6. Tim PKM Fikom Untar mempersiapkan segala detil perlengkapan yang dibutuhkan untuk pelaksanaan kegiatan, seperti video, pembuatan materi presentasi, penyediaan goodie bag dan souvenir untuk pihak mitra dan peserta, dll.

7. Tim PKM Fikom Untar melakukan koordinasi akhir untuk menghindari permasalahan teknis supaya kegiatan bisa diselenggarakan dengan lancar.

8. Pelaksanaan workshop kegiatan di Kafe 9Cups, samping Kampus 1 Universitas Tarumanagara, Jakarta Barat.

9. Penyusunan laporan kegiatan PKM

10. Pengumpulan laporan akhir kegiatan PKM, laporan keuangan dan log book kegiatan.

\section{HASIL DAN PEMBAHASAN}

Susunan kepanitian adalah sebagai berikut:

- Ketua Tim Kegiatan PKM (Pemberdayaan Kepada Masyarakat): Diah Ayu Candraningrum

- Mitra: Moh. Taufik. S (Pemilik dan pengelola Warung Bakso Mahkota)

- Narsum 1: Nila Matsuna (Reporter Program Feature MNC TV)

- Narsum 2: Farid Rusdi, S.S, M.Si

Jadwal kegiatan PKM dapat dilihat pada Tabel 1. Sebelum sesi pemberian materi, peserta ( 9 orang) diminta mengisi kuisioner untuk mengetahui latar belakang dan pengetahuan dasar tentang konsep komunikasi pemasaran di era modern. Namun karena keterbatasan pengetahuan dan pendidikan yang mereka miliki, kuesioner dengan pertanyaan terbuka pun dibacakan dan dianggap sebagai sebuah kegiatan wawancara. Daftar Peserta kegiatan PKM Bakso Mahkota dan kuesioner kegiatan PKM dapat dilihat pada Tabel 2 dan Gambar 1.

\section{Tabel 1}

Jadwal Kegiatan PKM

\begin{tabular}{lll}
\hline Waktu & Acara & Keterangan \\
\hline $17.45-18.00$ & $\begin{array}{l}\text { Mulai Makan dan minum untuk Jam 18.00 Mulai Acara } \\
\text { peserta maupun narasumber }\end{array}$
\end{tabular}


$18.00-18.05$ Perkenalan

18.05 - 18.10 Sambutan dari Ketua PKM

18.10 - 18.15 Perkenalan Narasumber

18.15 - 18.30 Diskusi Narsum 1

18.30 - 18.45 Diskusi Narsum 2

18.45 - 18.55 Tanya Jawab

18.55 - 19.00 Penutupan
Ibu Diah Ayu Candraningrum

Narsum 1 : Nila Matsuna

Sebagai Reporter Program Feature MNC TV

Narsum 2 : Farid Rusdi

Penyerahan Sertifikat dan Hadiah kepada Mitra

Penyerahan Sertifikat kepada Narasumber 1 (Nila Matsuna)

\section{Tabel 2}

Daftar Peserta kegiatan PKM Bakso Mahkota

\begin{tabular}{lll}
\hline No & Nama & Pekerjaan \\
\hline 1. & Bp. Hartoyo & Penjual warung makan \\
2. & Bp. Sakri & Penjual warung makan \\
3. & Ibu Mundira & Penjual warung makan \\
4. & Ibu Badriah & Penjual warung makan \\
5. & Bp. Idon & Pedagang gado-gado \\
6. & Bp. Agun & Pedagang telur dadar gulung \\
7. & Bp. Tarjianto & Pedagang minuman \\
8. & Bp. Bapri & Pedagang bubur ayam \\
9. & Bp. Taufik & Pengelola Warung Bakso Mahkota (mitra) \\
\hline
\end{tabular}

\section{Gambar 1}

\section{Kuesioner Kegiatan PKM}

\section{Kuesioner Kegiatan PKM Fikom Untar \\ Pengelolaan Media Sebagai Sarana Promosi \\ Usaha Warung Bakso Mahkota}

Jakarta, 7 November 2019

1. Apakah bapak/ibu mengetahui jenis-jenis sarana promosi digital untuk mempromosikan usaha kuliner bapak/ibu? Jika ya, sebutkan apa saja?

2. Apakah bapak/ibu suka menonton siaran televisi setiap hari? (Y/T)

3. Apakah bapak/ibu suka mendengarkan siaran radio setiap hari? $(\mathrm{Y} / \mathrm{T})$

4. Apakah bapak/ibu memiliki dan aktif menggunakan media sosial? (Y/T)

5. Apakah usaha yang dilakukan bapak/ibu sudah bekerjasama dengan system layanan online? $(\mathrm{Y} / \mathrm{T})$

6. Apakah bapak/ibu pernah mendengar istilah "foodblogger" atau "foodvlogger"? (Y/T)

7. Setelah mengikuti kegiatan ini, apakah bapak/ibu ingin menerapkan salah satu kegiatan promosi yang telah disebutkan di atas (tv, radio, media sosial, sistem layanan online, foodblogger)? Jika ya, sebutkan dan jelaskan mengapa? 
Dari hasil wawancara yang telah dilakukan saat kegiatan PKM berlangsung, menunjukkan bahwa sebagian besar peserta telah mengenal dan mengetahui media sosial, namun mereka belum menggunakannya secara optimal. "Saya belum pernah mengetahui jenis-jenis sarana promosi digital untuk mempromosikan usaha kuliner" (Bapri).

Namun sebagian yang lain, mengaku tidak mengetahui bagaimana menggunakan media sosial untuk promosi usaha kulinernya. Hal ini disebabkan karena mereka sibuk berdagang dan juga tidak ada waktu untuk menggunakan media sosial dalam waktu lama. "Saya tahu, bisa pakai online atau televisi” (Mundira).

Yang menarik, ada pula yang telah memiliki media sosial namun mereka lebih sering menonton televisi setiap hari untuk mendapatkan informasi. Tetapi, tidak ada yang masih mendengarkan siaran radio setiap harinya. Mayoritas pedagang juga tidak mengerti konsep foodblogger atau foodvlogger yang menjadi tren di konsep pemasaran modern saat ini.

Kegiatan dilaksanakan pada hari Jumat (7 November 2019) jam 18.00 - 20.00 WIB. Bertempat di Kedai Kopi 9 Cups di samping gedung Kampus 1 Universitas Tarumanagara Grogol, Jakarta Barat, kegiatan ini dihadiri oleh 9 peserta termasuk di antara mitra pemilik dan pengelola Warung Bakso Mahkota, 3 dosen anggota tim PKM dan 2 mahasiswa anggota tim PKM serta 1 narasumber reporter program kuliner dari stasiun televisi MNC TV. Foto bersama narasumber dapat dilihat pada Gambar 2.

\section{Gambar 2}

\section{Peserta Berfoto Bersama Narasumber dan Tim PKM}

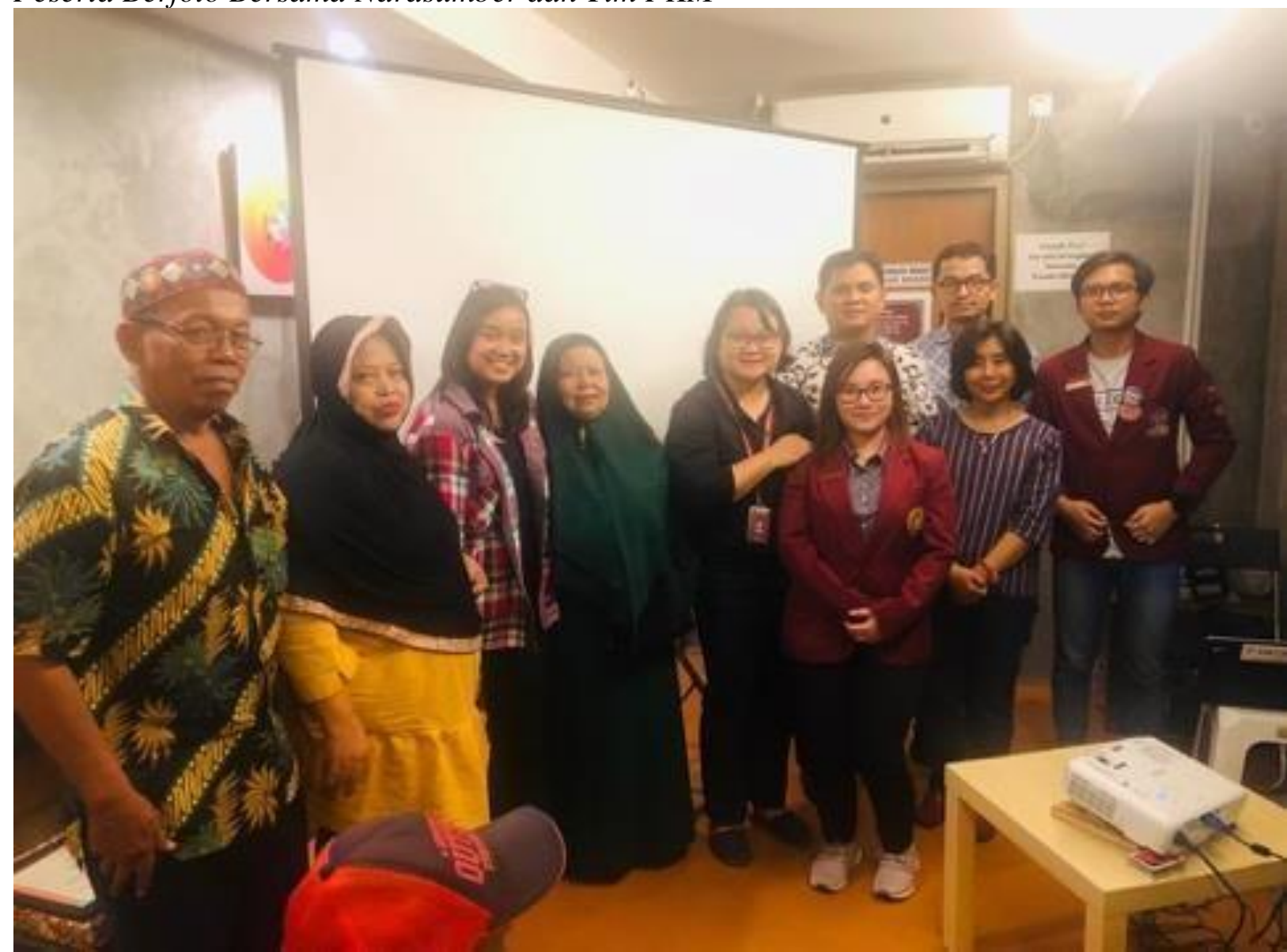


Sesuai jadwal acara yang telah dibuat sebelumnya, kegiatan diawali dengan pembukaan dan pemberian kata sambutan oleh Ketua tim PKM yakni Diah Ayu Candraningrum. Dalam sambutannya, disebutkan bahwa kegiatan ini merupakan salah satu tugas dosen dalam menjalankan Tri Dharma Perguruan Tinggi yakni mencerdaskan seluruh masyarakat Indonesia tanpa terkecuali.

Acara selanjutnya adalah pemberian materi oleh tiga narasumber yakni anggota tim dosen PKM Farid Rusdi, reporter program kuliner MNC TV, Nila Matsuna dan pengelola mitra Warung Bakso Mahkota, Moh. Taufik. Namun karena pengelola mitra warung bakso Mahkota juga menjalankan pekerjaan di salah satu perusahaan BUMN, dia datang terlambat.

Dalam materinya, Nila menjelaskan bagaimana sebuah tempat makan atau penjual kuliner mampu mendapatkan publikasi dari liputan televisi. Dia mencontohkan beberapa cuplikan program kuliner yang pernah dibuatnya dan ditayangkan di program kuliner MNCTV. Menurut Nila, keunikan dan kekhasan menjadi kunci utama sebuah restoran atau sajian akan mendapat perhatian dari media. Sambutan ketua tim PKM dan penyampaian materi oleh narasumber dapat dilihat pada Gambar 3. Materi berikutnya disampaikan oleh dosen anggota tim PKM, Farid Rusdi, yang menyampaikan perihal perkembangan media sosial bagi kegiatan promosi. Hal ini penting karena saat ini dunia memasuki era digital dimana hampir semua kalangan mulai mengenal, menggunakan bahkan kecanduan media sosial. Karena itu, sangat penting bagi masyarakat untuk bisa menggunakan media sosial dengan baik dan benar serta penuh tanggung jawab.

Terakhir, penjelasan dari pihak mitra PKM yakni pemilik dan pengelola Warung Bakso Mahkota, Moh. Taufik, yang datang terlambat. Dia menjelaskan bahwa saat ini warung milik orang tua yang sekarang dikelola bersama adiknya ini telah menggunakan media promosi menggunakan media sosial. Dia juga telah bekerjasama dengan pihak system antar makanan online selama beberapa bulan terakhir.

Hasilnya, terjadi pertumbuhan penjualan bakso yang signifikan dibandingkan sebelum pihaknya menggunakan promosi media online. Hal ini disebabkan karena jangkauan media online lebih luas daripada sekedar menunggu pelanggan yang berkunjung ke gerai baksonya. Penyampaian materi oleh dosen anggota tim PKM dan penjelasan dari pihak mitra PKM dapat dilihat pada Gambar 4.

Ketika kegiatan pemberian materi selesai, banyak peserta yang mengajukan pertanyaan perihal masalah yang mereka hadapi dalam kehidupan sehari-hari. Misalnya bagaimana mempromosikan produk yang sudah bermerek yang mereka jual, atau bagaimana cara mengembangkan bisnis mereka sehingga berskala lebih luas dan lebih besar. Antusiasme peserta tampak jelas penuh rasa ingin tahu karena menurut mereka, informasi yang mereka dapatkan adalah termasuk baru dan jarang mereka dapatkan.

Harapannya, mereka dapat mengimplementasikan materi yang telah diberikan dan juga bisa disebarkan kepada teman-teman lain sesame pedagang kaki lima, sehingga mereka bisa mendapatkan manfaat yang lebih dari media sosial maupun media konvensional. Antusiasme peserta dapat dilihat pada Gambar 5.

\section{KESIMPULAN}

Pelaksanaan kegiatan PKM tentang pengenalan konsep promosi lewat media televisi kepada peserta dari kalangan pedagang kuliner kaki lima, dapat disimpulkan:

1. Peserta yang berasal dari latar belakang pedagang kaki lima belum mengerti dan memahami konsep berpromosi di media televisi. Selama ini, mereka hanya menonton program-program 
televisi sekedar untuk hiburan semata. Hal ini dapat dimaklumi, karena tingkat pendidikan dan pengetahuan mereka yang terbatas.

2. Lewat kegiatan seperti ini, peserta menjadi paham peran penting televisi dalam menyebarluaskan kepada masyarakat tentang bisnis yang dijalani. Namun untuk melakukan hal tersebut, seperti mengundang jurnalis untuk meliput lokasi rumah makan, kedai atau gerobak dagangan mereka, para pedagang itu mengaku tidak bisa melakukannya karena ada keterbatasan.

3. Para pedagang makanan jalanan ini sebetulnya memiliki keinginan untuk mengembangkan bisnis mereka. Namun, keterbatasan pengetahuan, dana, waktu, kesempatan, dan sarana serta prasarana, membuat mereka harus menerima kondisi yang ada saat ini. Karena itu, mereka sangat tertarik dengan kegiatan penambah pengetahuan tentang bisnis mereka seperti ini, sehingga membuat mereka terpacu untuk melakukan kegiatan yang lebih baik demi suksesnya bisnis mereka.

\section{Gambar 3.}

(a) Ketua Tim PKM Diah Ayu Candraningrum Tengah Memberikan Kata Sambutan

(b) Reporter Program Kuliner MNCTV Nila Matsuna Tengah Menyampaikan Materi tentang Pentingnya Promosi Dagangan di Media

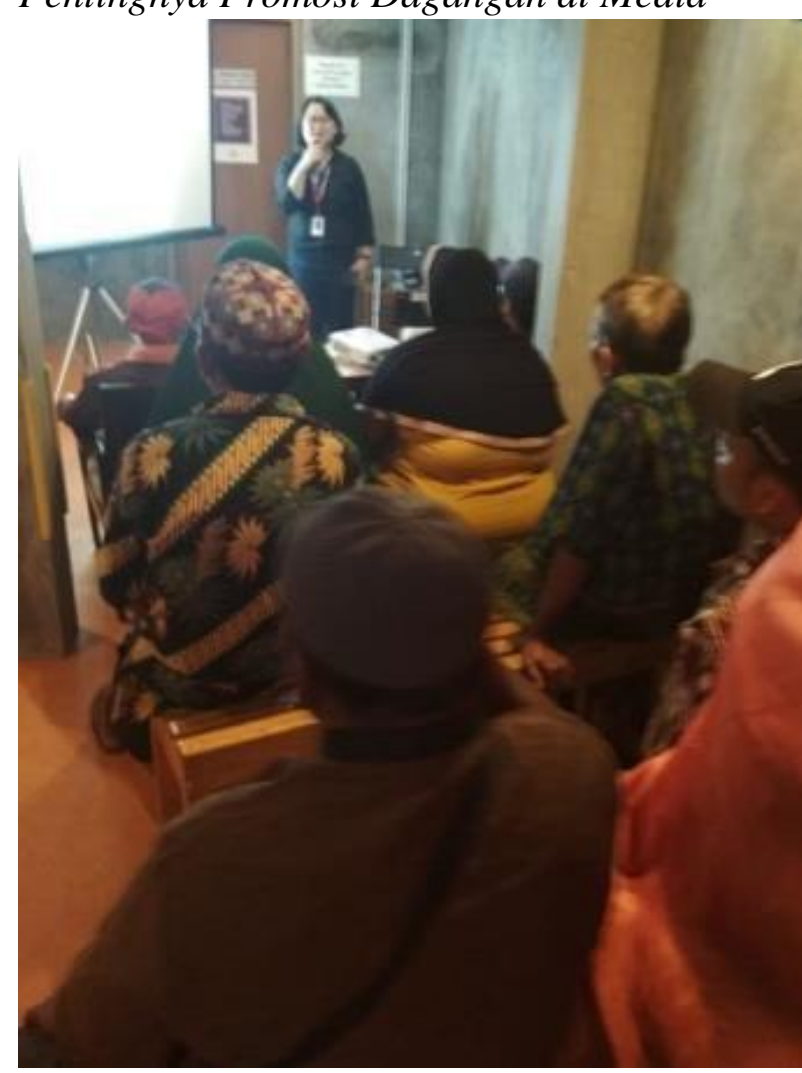

(a)

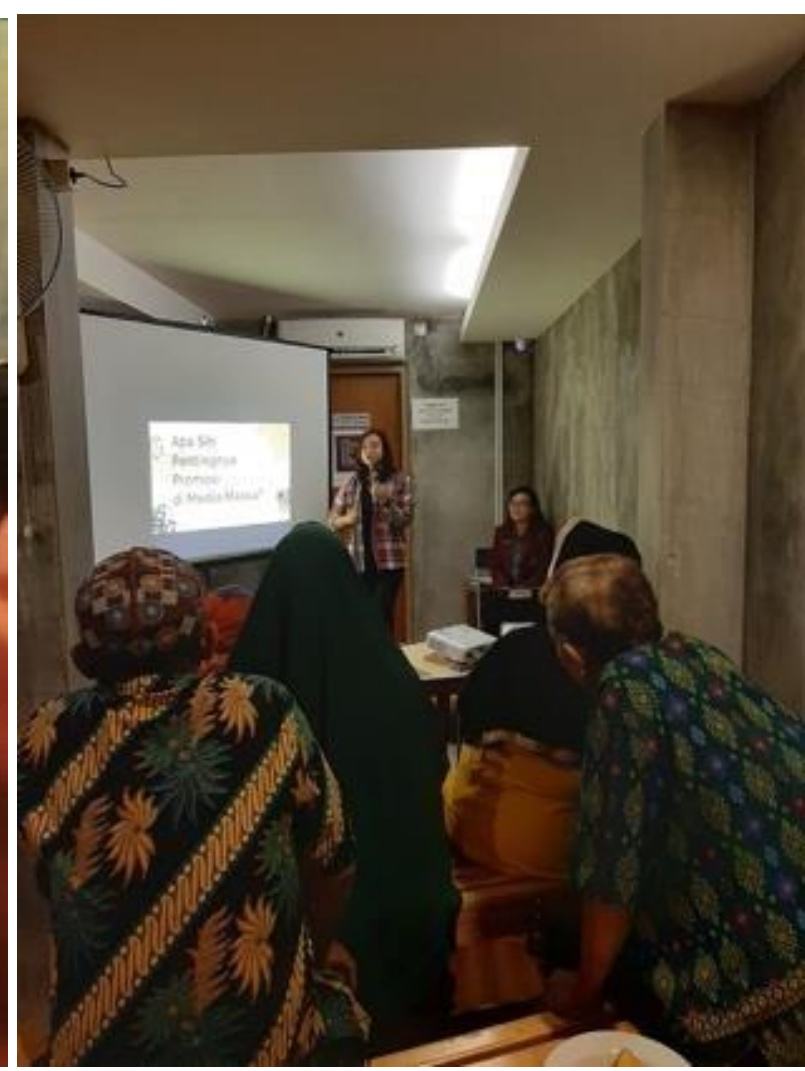

(b) 


\section{Gambar 4.}

(a) Dosen anggota tim PKM, Farid Rusdi, Menyampaikan Materi tentang Perkembangan Media Sosial dalam Kegiatan Bisnis

(b) Mitra PKM pemilik dan pengelola Warung Bakso Mahkota Menyampaikan Materi tentang Pengalaman Warungnya Menggunakan Media Digital dan Sistem Pemasaran Online dalam Kegiatan Bisnis

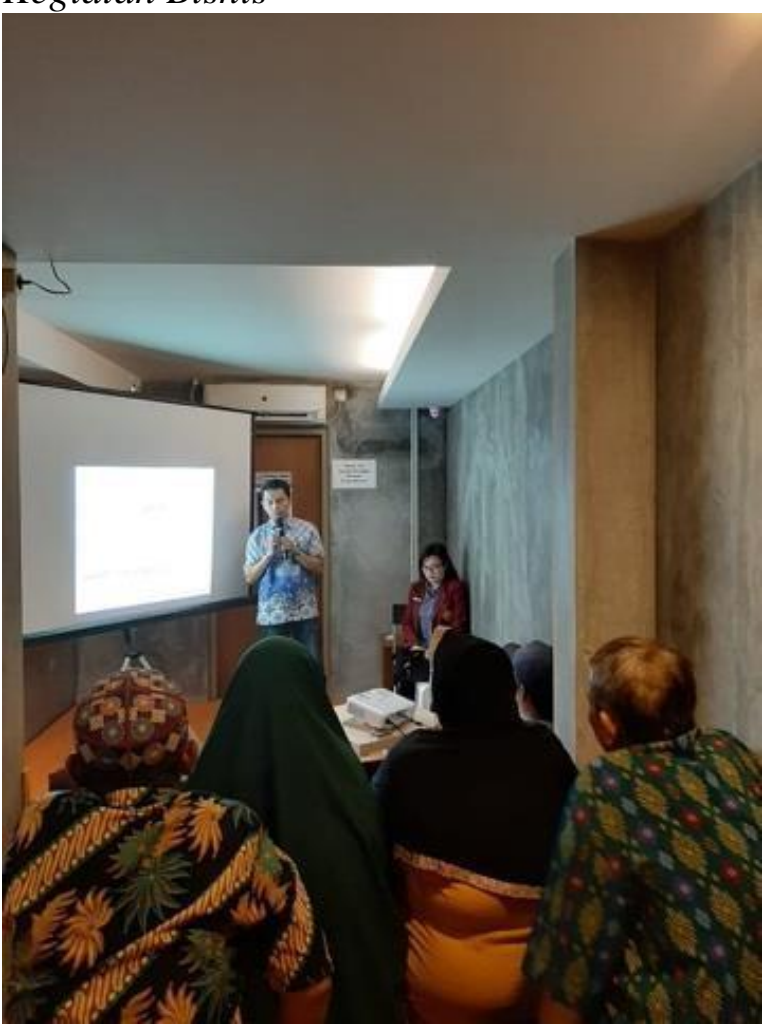

(a)

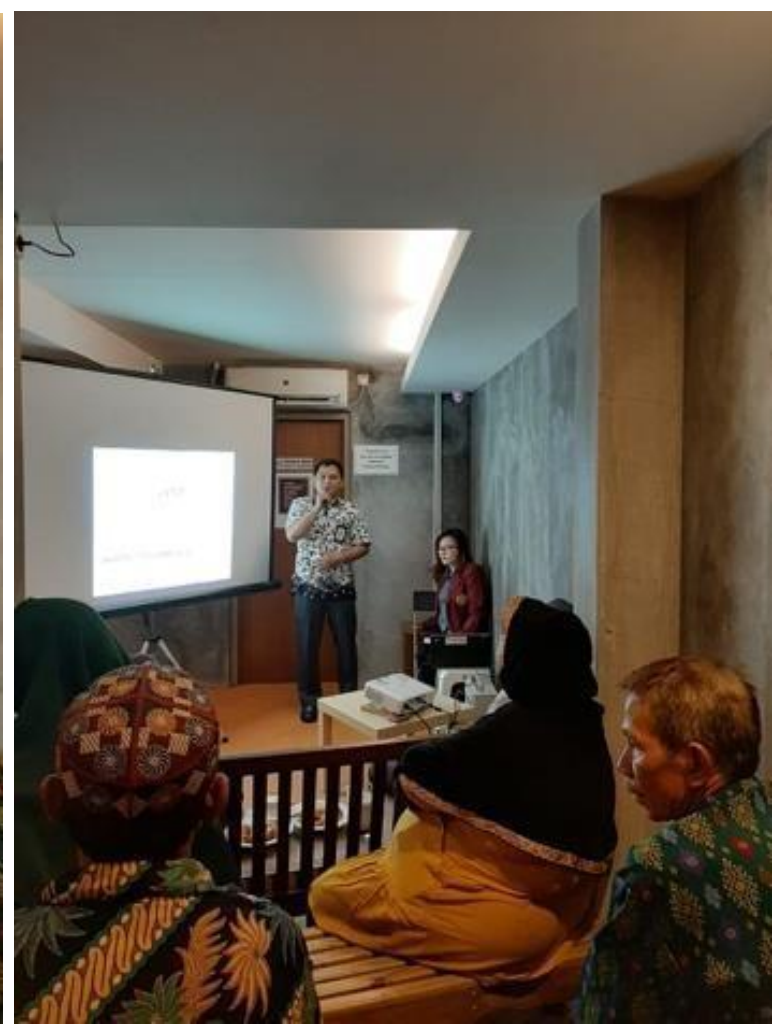

(b)

\section{Gambar 5.}

Antusiasme Peserta Mendengarkan dan Memperhatikan Sesi Pemberian Materi

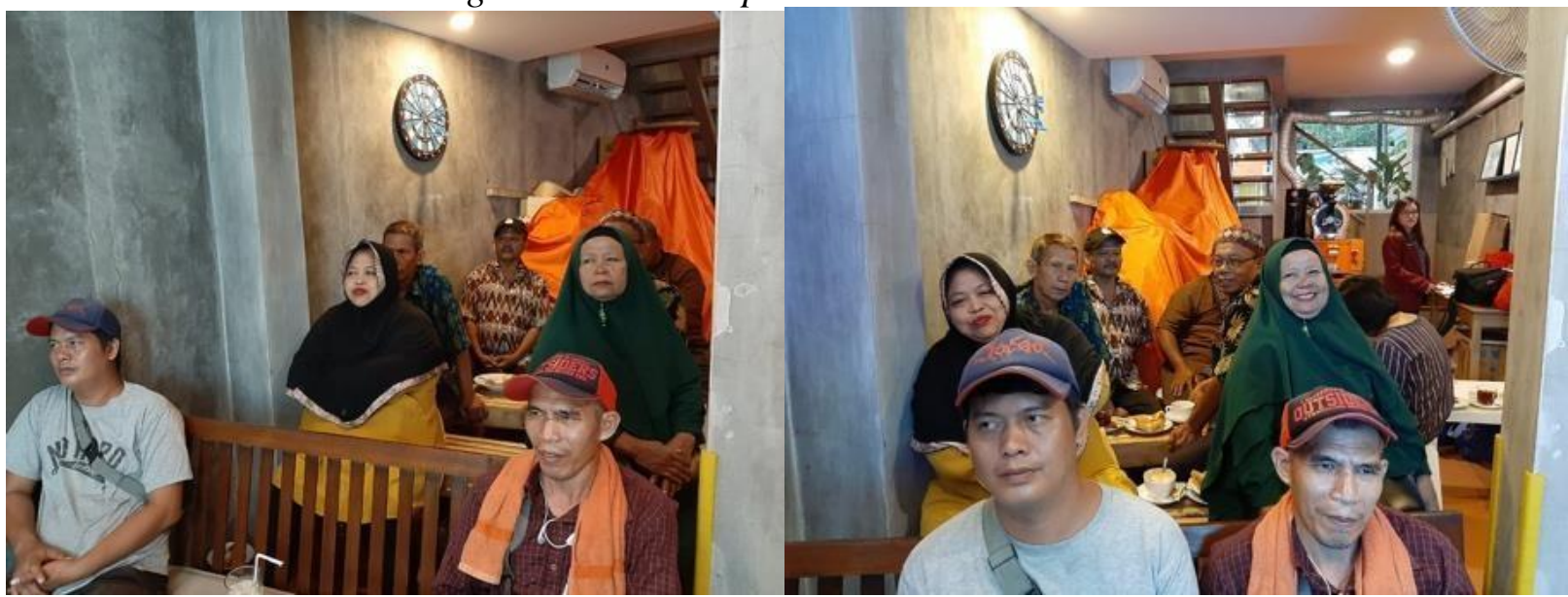

\section{REFERENSI}

Candraningrum, D. A. (2018). Gangguan komunikasi publik dan penurunan brand engagement di perusahaan Toys"R"Us. Jurnal Komunikasi Global, 164-174.

Hussein, A. S. (2012). Social marketing: Strategi menuju Indonesia yang lebih baik. http://sabilfeb.lecture.ub.ac.id/files/2014/03/Social-Marketing-final.pdf: 
Kotler, P. N. (2002). Social Marketing: Improving the quality of life. Sage Publication.

Rahayu, N. (2017, Juli 25). UMKM diminta beradaptasi dengan teknologi digital untuk naik kelas. Warta Ekonomi. https://www.wartaekonomi.co.id/read148847/umkm-diminta-beradaptasidengan-teknologi-digital-untuk-naik-kelas.

Rusdi, F. (2017). Strategi media online menjangkau generasi millenial. Research Week. Indonesia.

Wahyudi. (2017, Oktober 26). Era digital, pengusaha ukm harus melek teknologi. Okezone. https://economy.okezone.com/read/2017/10/26/320/1802917/era-digital-pengusaha-ukmharus-melek-teknologi. 